\title{
Postmodern Masal Uyarlaması Olarak Sihirli Orman Filmi
}

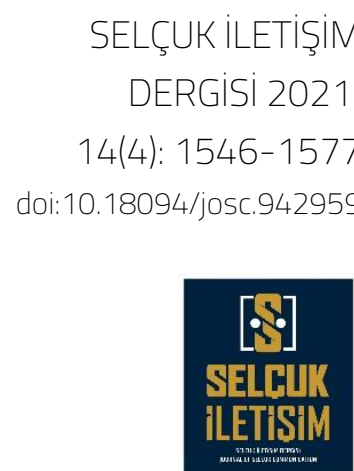

\section{Özge Sayılgan, Gökçen CIvaş}

ÖZ

Bu araştırma kapsamında Sihirli Orman (2014) filmi postmodern bir masal uyarlaması olarak incelenmiş, ayrıca anti-masal kavramsallaştırması bağlamında tartışmaya açılmıştır. Dört farkı masal içeriği ( Kırmızı Başıkı Kız, Rapunzel, Jack ve Fasulye Sırı̆ı̆, Külkedis) ile bu masalların merkezi kahramanlarının yolculuklarını bir orman içinde kesiş̧tirerek metinlerarası bir anlatı inşa eden film özellikle kahramanların toplumsal cinsiyet rollerine yapılan dönüştürücü müdahaleler ile kendi istenç ve kaderlerini sorgulamaya açmaları sonucunda eleştirel bir perspektife yerleşmektedir. Araştırmanın ilk aşamasında Campbell'ın Kahramanın yolculuğu modelinden yola çıkılarak metin analizi yapılmış, her kahramanın birbiri içine girip, yeni sözdizim olasılıklarını açan yolculukları çözümlenmiştir. Bu çalışma kapsamında klasik anlatıya yapılan postmodern ve dönüştürücü etkiler bulunmuştur. İkinci aşamada ise Gérard Genette'in anlatı içeren metinler için önerdiği söylem analizi metoduna başvurulmuştur. Araştırmanın sonucunda Sihirli Orman filminin, her ne kadar postmodern bir anlatı olarak kabul edilse de, hikaye (içerik) düzeyinde var olan toplumsal iktidar ilişkilerini, toplumsal cinsiyet pratiklerini ve ataerkil düşünceyi yeniden üreten söylemlere sahip olduğu bulunmuştur.

Anahtar Sözcükler: Postmodern, Anti-Masal, Metinlerarasılık, Söylem, Anlatı
ÖZGE SAYILGAN
GÖKÇEN CIVAŞ
Dr. Öğr. Üyesi
Dr. Öğr. Üyesi
İstanbul Medeniyet Üniversitesi
Maltepe Üniversitesi
ozgesayilgan@gmail.com
gokcencivas@gmail.com
ORCID ID: 0000-0001-7870-0910
ORCID ID: 0000-0002-2708-3198

SELÇUK ILETIŞIM DERGISI 2021; 14(4): 1546-1577

doi: 10.18094/josc.942959

Geliş Tarihi: 25.05.2021 Kabul Tarihi: 15.09.2021 Yayın Tarihi: 25.10.2021 


\title{
The Film Into the Woods as a Postmodern Fairytale Adaptation
}

JOURNAL OF SELÇUK

COMMUNICATION 2021;

14(4): 1546-1577

doi: $10.18094 /$ josc. 942959

[अ]

SEELCIIK

ILETISTM

\section{Özge Sayılgan, Gökçen Cıvaş}

\begin{abstract}
In the scope of this research, the film Into the Woods has been analyzed as a postmodern fairytale adaptation, besides it has been discussed in the context of anti-fairytale. The film which constructs an intertextual narrative with the intersection of four different fairytale contents (Little Red Riding Hood, Rapunzel, Jack and the Beanstalk, Cinderella) and the journey of central heroes / heroines from these fairytales, places into a critical perspective by transforming interventions on gender roles and the characters' interrogation on their own will and fate. As a first stage of the research, a textual analysis has been made departing from Campbell's model of Hero's Journey and analyzed the paths open for new possible syntax of each hero / heroine's intertwining journey. In the scope of this stage, postmodern and transforming effects to the classical narrative has been found. As a second stage, Gérard Genette's method which offers a discourse analysis for narrative texts is applied. Consequently, although its postmodern narrative style, it is found that the film Into the Woods reproduces existing social power relations, gender practices and the patriarchal thinking in the level of narrative (content) discourse.
\end{abstract}

Keywords: Postmodern, Anti-Fairytale, Intertextuality, Discourse, Narrative

\author{
ÖZGE SAYILGAN \\ Asst. Prof. \\ GÖKÇEN CIVAŞ \\ Istanbul Medeniyet University \\ Asst. Prof. \\ ozgesayilgan@gmail.com \\ Maltepe University \\ gokcencivas@gmail.com \\ ORCID ID: 0000-0001-7870-0910 \\ ORCID ID: 0000-0002-2708-3198 \\ JOURNAL OF SELÇUK COMMUNICATION 2021; 14(4): 1546-1577 \\ doi: $10.18094 /$ josc. 942959
}




\section{GiRiş}

Sözlü kültür mirası masallar medya teknolojisindeki gelişmelere bağıı olarak, döneminin egemen medya biçimleri içinde tekrar tekrar uyarlanarak günümüze gelmiştir. Türk Dil Kurumu Güncel Türkçe Sözlük'e göre (2020) masal, "genellikle halkın yarattığı, hayale dayanan, sözlü gelenekte yaşayan, çoğunlukla insanlar, hayvanlar ile cadı, cin, dev, peri vb. varlıkların başından geçen olağanüstü olayları anlatan edebî tür" şeklinde tanımlanmıştır. Bir anlatıının ağzından anlatılmak ve dinleyici tarafından dinlenmek üzere tasarlanmış bu kültürel formlar önce insan belleğinde kayıtlanmış olsa da bir kayıt teknolojisi olarak yazının bulunmasından itibaren belleğin muğlaklığından çıkmaya başlamıştır. Yazının baskı teknolojisiyle kitleselleşmesi ve yaygınlaşma sürecinde yüzlerce yıllık halk masalları masal yazarları tarafından derlenmiş; önce yazıya geçirilmiş fakat sonrasında artık yazıya uyarlanmaya başlamışlardır. Bununla birlikte her masal uyarlaması, yazarının yaşadığı dönemin egemen değerlerinin doğallaştırıldığı bir yeniden yazım süreci olarak okunmaya açıkır. Yazı ile somutlaşma, aynı zamanda sözlü kültürün hikâye anlatıcısının dilinden dökülen masalların esnekliğinin yerine geçmiştir. "Bütün hikâye anlatıcılarının beslendiği kaynak, ağızdan ağıza aktarılan deneyimdir. Hikâyeleri yazıya geçirenler arasında en büyük olanlar, adı sanı bilinmeyen sayısız hikâyecinin anlattıklarına en sadık kalanlardır" (Benjamin, 1995, s. 78). Buna karşın, bu sadakat istense bile çok zor bir görevdir. Çünkü sözlü kültürün masal anlatıcısının beden dili, sesi, mimikleri ve duraklamaları performatiftir ve masalın bir parçası olarak işler.

Her kayıt teknolojisi yeni uyarlama olanakları ve dili içinde masalları tekrar tekrar yeniden yazmaya devam etmiştir. On dokuzuncu yüzyılın sonunda sinematografın bir görüntü kayıt cihazı olarak icadından çok kısa bir süre sonra, yirminci yüzyılın başında hareketin kaydedilmesini sağlayan bu yeni teknolojinin aynı zamanda hikâye anlatımında da kullanılabileceğinin keşfedilmesiyle masallar sinemaya da uyarlanmaya başlamıştır. Tarihsel süreçte dönüşümleri izlendiğinde masalların sabit ve değişmez anlatılar olarak değil, fakat içlerinde pek çok olasılık ve anlatı olanağını barındıran, anlatıldığı döneme, yere, kültüre, dile ve hatta aynı yer ve dönemde aynı masalı anlatan her anlatıcının ekleme, çıkarma ve dönüşümlerine açık esnek yapılar olarak işlendiklerini görebiliriz. Zaten masalların bu kadar uzun zaman boyunca yaşamaları onların esnek metinler olmasına bağlıdır. Yine de her anlatıcı için o masalı bir başkasından ayıran veya bir başkasına yaklaştıran ortak karakter, kahraman, çatışma ve olay parçaları 
da sabitleyici arketipler olarak işler ve bunlar birbiriyle ilişkisiz, farklı yer ve dönemlerde yaşamış insanların belleklerinden benzer biçimlerde dökülebilmektedir. "Bir peri masalı yazılı ve sözlü versiyonları arasında birbirine döner, basılı ile performans arasında ve kitle iletişim araçlarının ortaya çıktığından beri de sayfayla ekran arasında sürekli gidip gelir (...)" (Warner, 2015, s. 56).

Masal metinlerinin kolektif bilinçaltından kaynaklanan karakter ve olay arketiplerinin üzerine inşa edilmiş yapılar olarak çözümleyen yapısalcı yaklaşımlar, masalların aşamalarını, kullandıkları karakter ve karakterler arası ilişkilere dayalı olayları sınıflandırmış ve işlevlerini ortaya koymaya girişmişlerdir. Örneğin; Vladimir Propp, Masalın Biçimbilimi ve Olağanüstü Masalların Dönüşümleri (2008) başlıklı araştırmasında, Rus halk masallarını incelemiş ve bu masallarda ortak bulgulanan 31 işlevi ortaya koymuştur.

Karşılaştırmalı mitoloji üzerine çalışan Joseph Campbell ise Sigmund Freud ve Carl G. Jung'un mitleri psikoloji alanında nasıl kullandıklarını incelemiş (Young, 2005) ve çalışmalarını edebiyat, antropoloji ve sanat gibi alanları da kapsayacak şekilde genişletmiştir. Campbell da masallarda karşılaşılan ortak karakter arketiplerinden başka olay arketiplerini ve bunların aşamalarını modelleştirerek Kahramanın döngüsel yolculuğunu açıklamaya çalışmıştır. Buna karşın, son dönemde masalların sinemaya yapılan çağdaş uyarlamalarında, binlerce yıllık karakter ve olay arketiplerinin yerinden edildiği ve başka olasılıkların araştırıldı̆ı, yerlerinin değiştirildiği, bozuntuya uğratıldığı veya farklı masalların ve masal kahramanlarının bir araya getirildiği yeni hikâyeler aktarılmaya başlanmıştır.

Örneğin, Disney'in animasyon alanında yaptığı prenses anlatılarında özellikle kadın kahramanların dönüşümüne yönelik izlediği stratejiler dikkat çekici olduğu kadar derinlemesine incelenmeye açık yeni anlatılar sunmuştur (Bostan \& Kırel, 2018). Masal uyarlamaları sadece animasyon tekniği ile değil, gerçek zamanlı filmlere de uyarlanmış ve özellikle iki binli yılların ilk yarısında pek çoğu özellikle yine kadın kahraman temsilinin dönüşümünü odağına alan çeşitli filmler yapılmıştır. Bu masal uyarlamaları ve kullandıkları yöntemler postmodern anlatılar, karşı-masal kavramsallaştırması ve feminist kuram perspektifinden çözümlenmişlerdir. Özellikle kadın ve erkek toplumsal cinsiyet rollerinin dönüşümüne odaklanan pek çok araştırma bulunmaktadır. Bu araştırmanın önemi, Kahramanın döngüsel yolculuk modeli bağlamında bir çözümleme önermesi ve karakterlerin dışında, olay arketiplerine yapılan 
postmodern müdahalelerin yeni anlatı formlarını nasıl ve hangi söylemle dönüştürdüğüne odaklanmasındadır.

Bu araştırma kapsamında sinemaya uyarlanmış masal karakterlerinin toplumsal cinsiyet rollerini tartışmaya açan girişimler kadar kahramanın yolculuğunun döngüselliğini kıran, bozuntuya uğratan ve farklı kahraman yollarını kesiştirip çarpıştıran olay arketiplerinin ve bunların dizilimindeki dönüşümün de çözümlenmesi amaçlanmıştır. Araştırmanın problematiğini, postmodern karakterlerin başından geçen, onların klasikleşmiş masallarda kendilerine biçilen toplumsal roller karşısındaki öznelleşme istemleriyle meydana gelen; ayrıca masal kurgusunu oluşturan olaylardaki dönüştürücü etkinin sonucunda ortaya çıkan postmodern anlatı stratejileri ile bunların ürettikleri söyleme ulaşılması oluşturmaktadır. Bu amaçla 2014 yılında Rob Marshall tarafından çekilen Sihirli Orman (Into the Woods) filmi incelenmiştir.

Sihirli Orman filminin çözümlenmesinde Campbell'ın olay arketipleri sınıflandırması ve Yola çıkış / Erginlenme / Dönüş aşamalarından faydalanılarak anlatı çözümlemesine başvurulmuş, böylece olay örgüsündeki postmodern sapmalar ile dönüştürücü müdahalelere ulaşılmıştır. Bu çözümlemeden yola çıkarak Gérard Genette'in anlatı içeren metinler için önerdiği söylem analizi metodu ile film anlatısının alt metinlerine ulaşılması amaçlanmıştır. Buna göre, postmodern müdahalelerin toplumsal cinsiyet ve karakter arketipleri ilişkisini dönüştürme stratejileri Sihirli Orman örneğinde nasıl işlemiştir? Olay arketiplerinin içerik ve sözdizimlerinde ne tür dönüşümlere yol açmıştır? Araştırmanın temel amacı, sinemada "postmodern masal uyarlama stratejilerinin klasik karakter ve olay arketiplerini nasıl dönüştürdüğü"ne ve bu dönüşümlerin yol açıı̆ı söyleme ulaşmaktır.

\section{POSTMODERN UYARLAMA, ANTI-MASAL VE METINLERARASILIK}

Masalların yeniden yazımları ve sinemaya uyarlanmalarını da içeren pek çok masal metni akademik araştırmalar için ilgi çekici olmuştur. Bu araştırmaların önemli bir bölümü, bu yeniden yazımlarda özellikle kadın ve erkek toplumsal cinsiyet rollerinin yeniden üretimi veya yapısökümü üzerine eğilmiştir.

"20. yüzyılın ikinci yarısı ve 21. yüzyıl, metinleri yeniden yazarak deforme etme noktasında feminist ve postmodernist yazını ortak bir zeminde birleştirir. Bu iki düşünce akımı kanıtlanabilir, sabit gerçekliğin söz konusu olmadığına vurgu yaparken dönemlere ait baskın söylemlerin ve bu söylemlerin belirlediği hakikatin, ideolojilere ve buna bağlı birçok etkene göre şekillendiğini savunur" (Ulu Aslan, 2018, s. 209). 
Postmodernizm ile feminizmin birleştiği nokta, birinin sabit ve mutlak anlamlılığa, diğerinin ise ataerkil merkeziyetçi mutlaklığa karşı bir öteki konumunu öneriyor olmalarıdır. Merkezsizlik, çok anlamlıık, katmanlıık, çoklu bakış açısı ve yorumlama / söylem çokluğu ile parodi, pastiş, kolaj, metinlerarasılık, çalıntılama, dönüştürme vb. teknik ve yöntemlerle sözün ve imgenin üretiminde yeni bir anlayışın kapısını açmışlardır.

Masalları odağına alan araştırmalar, masalın çağlar boyunca çeşitli medya içinde uyarlanmasına bağlı olarak masalın bir anlatı veya yazın formunda incelendiği edebiyat çalışmaları ile performatif ve temsili uyarlamalarını odağına alan tiyatro, sinema ve etkileşimli medya çalışmaları alanlarında yapılmaya devam etmektedir. Bununla birlikte özellikle kadın karakterlerin yeniden yazıldığı veya temsil edildiği postmodern masallar hem anlatı / yazın alanında, hem de temsili ve dramatik alanda yeniden düşünülmeye, tasarlanmaya ve yorumlanmaya devam etmektedir. Bu nedenle postmodern masal uyarlamalarını odağına alan bir alanyazın içinde edebiyat araştırmaları ile sinema araştırmaları gibi disiplinlerin alana ortak katkı sağladığı söylenebilir. Tam da bu nedenle, bu araştırmanın örneklemi bir sinema filmi olsa da edebiyat çalışmalarında yapıımış bazı çalışmalar da postmodern masalın dönüşümü üzerine değerli bulgular içermeleri bakımından bu çalışmanın alanyazın taraması içine dahil edilmiştir. Bu araştırmaların önemli bir bölümü de feminist perspektiften yürütülmüş toplumsal cinsiyet odağında çözümlemeler olmaları nedeniyle özellikle feminist alanyazını genişleten çalışmalar olarak da okunabilirler.

Örneğin, Nunila Lopez'in Vejeteryan Külkedisi masalının, Grimm Kardeşler'in Külkedisi masalı ile karşılaştırmalı bir şekilde, feminist yaklaşımdan ideolojik analizini amaçlayan Agvan ve Asutay, anti-masal ya da karşı masal terimi ile tanımladıkları, klasik masal anlayışını ters yüz eden, klasik masallardaki toplumun çizmiş olduğu cinsiyet rollerinden arındıran masalların dekonstrüktif (yapıbozumcu) yönüne işaret ederler (2018). Bir anti-masal örneği olarak Vejeteryan Külkedisi, Lopez tarafından büyükler için gerçekçi öyküler alt başlığı ile edebiyat alanında yazılmıştır. Bununla birlikte, masalın bu yeniden yazımında metin, başka bir yazılı versiyon olan Grimm Kardeşler'in Külkedisi masalı ile karşılaştırmalı bir biçimde merkezdeki kadın karakter olan Külkedisi üzerinden, feminist eleştirel perspektiften dönüştürülmüştür ve bu anlamda aslında yapısökümcü bir metindir. Bu bağlamda, masalların uyarlandıkları medya türü değişse de içinde üretildikleri toplumun egemen değerleri ile bunlarla çatışma halinde olan ideolojilerden bağımsız olmadıkları ileri sürülebilir. Feminist açıdan, anti-Külkedisi, ataerkil düzen karşısında kadının 
toplumsal cinsiyet algısını yeniden kuran bir karşı masalın kahramanıdır. Fakat bunu Grimm Kardeşler'in yazmış olduğu orijinal versiyonu bozuntuya uğratarak, yapısöküme başvurarak gerçekleştirir (Agvan \& Asutay, 2018).

Ulus devletin, ataerkil ideolojinin, toplumsal cinsiyet eşitsizliğinin erkeğin lehine yükseldiği 17.19. yüzyıllarda yaygınlaşmış olan yazılı kültürün içinde masalların yeniden yazımlarının ataerkil söylemden bağımsız olmalarını düşünmek zordur. Benzer bir biçimde kültürel metinler ile sanat alanında görülmeye başlanan yapısökümcü müdahalelerin, odağında kadın ve erkek toplumsal cinsiyet rollerinin dönüşümünü bulunduran girişimlerin feminist ideolojinin de yükseldiği 20. yüzyılın ikinci yarısından itibaren görülmeye başlaması masal metinlerinin, diğer kültürel ürünlerde olduğu gibi, dönemlerinin ideolojik söylem ve perspektiflerine göre yeniden yazılabilen esnek metinler oldukları şeklindeki tanımlarını doğrular niteliktedir. Zipes' a göre, uygarlığın her yeni aşamasında, tarihin her yeni çağında masallardaki simgeler ve yapılandırmalar, toplumsal düzenin içindeki insanların gereksinimlerine ve çatışmalarına tepki olarak yeni anlamlar kazanmış, dönüştürülmüş veya elenmiş̧tir (Zipes, 2018, s. 35). Örnek olarak orijinal sözlü halk masallarının anaerkil dünya görüşü ve motiflerinin peş peşe ataerkilleşme aşamalarından geçerek Orta Çağ boyunca dönüştüğü görülmüştür (Göttner-Abendroth, 1980; akt. Zipes, 2018, s. 35). Tanrıça cadı figürü kötü kalpli bir peri veya üvey anneye; etkin ve genç bir prenses çevik bir erkek kahramana, ana soylu evlilikler baba soylu evlilik ve ilişkilere dönüşürken; anaerkil törenlere dayalı simgelerin özü zayıflatılıp etkisiz hale getirilmiş ve karakterin olgunlaşıp tamamlanmasını temel alan eylem modeli yerini yavaş yavaş baskının egemen olduğu ve servet odaklı bir niteliğe bırakmıştır (Zipes, 2018, s. 36)

15., 16. ve 17. yüzyıllarda yazıya geçirilirken Orta Çağ’a özgü monarşik - mutlakiyetçi ataerkillik ile biçimlenmiş (Zipes, 2018, s. 36) masal metinlerinin; postmodern müdahale ile feminist eleştirel perspektifin kesişim noktasındaki dönüştürülme biçimlerinde, parodi veya pastişlerinde veya metinlerarası ilişki ile yeniden yazılmalarında 20. yüzyılın ikinci yarısında yükselişe geçen feminist eleştirinin etkisini görmek mümkündür. Örneğin Zeynep Kaçar'ın Şimdi Uçuşa Geçiyoruz (2017) başlıklı oyununu seçerek, bu tiyatro uyarlamasını feminist eleştirel perspektiften çözümlemeyi amaçlayan araştırmasında Ulu Aslan (2018), parodi kullanımı üzerinden postmodern masal anlatısını ve yöntemlerini ortaya koymuştur. Ulu Aslan'a göre masal kahramanlarının yazar tarafından modern dünyaya bırakıldığı, "oyunda bilinçli olarak seçilen kadın masal kahramanları, yıllardır süre gelen, 
kendilerine biçilmiş kadere karşı gelerek gerçek yaşamın peşine düşmüştür. Olay örgüsü bu konu etrafında şekillenen bu parodi metinde, masalların ataerkil söylemlerine yapılan göndermelerle feminist bir bakış açısı benimsenmektedir" (Ulu Aslan, 2018, s. 219).

Sözlü kültürün mirası olan halk masalları Batı'da, örneğin 17. yüzyıl Fransa'sında masal yazarları tarafından yazıya geçirilirken dönemin salonlarında canlandırılan metinler olarak toplumsallaşma işlevinin yanı sıra kurumsallaşma sürecine de girmişstir. Toplumsallaşan ve kurumsallaşan masal bir yanıyla sacral, tehlikeli, çağa uymayan bağlarından koparılarak hijyenikleştirilecek (Moen'den akt. Tunalı, 2017, s. 369), fakat yazıyla sabitleştirilen bu hijyenik metinler, sözlü kültürün arkaik izlerinin bir bölümünü korurken kendi dönemlerinin egemen / ataerkil ideolojisi içinde yeniden kurulacaklardır. Dolayısıyla, yazıya uyarlanmaları sırasında bir yönüyle ataerkil ideolojiye yerleştirilen masalların, sözlü kültürden tamamen kopmamış olmasına benzer bir biçimde, postmodern masal uyarlamalarında da feminist yapısökümcü müdahalelere rağmen, ataerkil söylem ve ideolojinin tamamen terk edilmediği, hatta korunmaya devam ettiği görülebilmektedir.

Örneğin, postmodern dönem Disney prenses anlatılarını, Moana (Disney, 2016) filmi örneği üzerinden çözümleyen Bostan ve Kırel'e göre (2018), Disney'in 1937 yapımı Pamuk Prenses ve Yedi Cüceler uyarlamasından, 2017 yapımı Moana'ya kadar kadın temsilinin evcimen, pasif ve güzel kadından cesur, aktif ve bağımsız kadına evrildiği görülür. Buna karşın, bağımsız bir kadın karakteri merkezine alan ve romantik aşk içermeyen bir öykü olarak sunulmuş olan Moana örneğinde, "anlatı, kadın kahramanı erkek kahramanın "yol gösterici"liğine mecbur kıldığı gibi, yola devam edebilmek için erkeği ivileştirme sorumluluğuyla da karşı karşıya bırakır. Bu bağlamda postmodern bir masal uyarlaması olan Moana'da, klasik dönem uyarlamalarından çok da farklı olmayarak "masal formunun iktidarı sorgulayan değil ona destek olan" (Sezer, 2010) kalıbının sürdürüldüğü görülmektedir (...)" (Bostan \& Kırel, 2018, s. 26).

Disney'in 2014 yapımı filmi Malefiz (Maleficient) de Uyuyan Güzel masalının postmodern bir uyarlaması olarak özellikle eleştirel feminist söylemi ile analiz edilmiş örneklerden biridir. Malefiz'de kötü kalpli perinin ana karakter olması ve öykü içinde dönüşüm geçiren güçlü bir kadın karakter olarak yeniden tasviri ilgi çekici olmuştur. Disneyleştirme stratejisi içinde inşa edilen toplumsal cinsiyet ideolojisinin örtük yönlerini analiz eden Wendranirsa'ya göre (2014), Malefiz, her ne kadar güçlü bir kadın olarak çizilmiş olsa da yine baskı altında bir karakterdir. Erkek bir egemen olarak Kral için tehdit olarak görülen 
sihir gücü nedeniyle baskı altına alınmış ve yine cesur ve güçlü bir kadın olarak tasvir edilmesine karşın, iyi ve kötü kadın rolleri arasında kalması toplum tarafından belirlenen bir dikotomi olarak durmaktadır. Aynı zamanda benzer bir dikotomi kadını doğayla, erkeği ise kültür ve toplumla ilişkilendirilmesinde de bulunur. Malefiz doğayı ve anneliği, insan krallığı ise kültür ve medeniyeti temsil etmektedir (Wendranirsa, 2014, s. 77).

Agvan ve Asutay'ın da belirttiği gibi $(2018$, s. 227) masalın asıl kaygısı soru sormak değil, cevap vermektir. Masalların vermek istedikleri ders, aktarmak istedikleri mesaj ve söylemek istedikleri söz nettir. Bununla birlikte postmodern dönem masal uyarlamalarında, masalın iletisi netliğini kaybeder, öykü cevaplardan çok sorularla biter. Sözgelimi, dört farklı masalı bir araya getiren Sihirli Orman filmi için de aynı durum geçerlidir. Kafası karışmış masal kahramanlarının ormanda yönlerini kaybettikleri, istem yönlerini sorguladıkları ve değiştirdikleri, ne istediklerini bilmedikleri ve öyküden kaynaklanan kaderlerinden öznelleşerek kurtulmaya çabalarken bir sonraki adımlarının belirsizliği aynı zamanda bu netsizleştirme pratiğinin örnekleri olarak da okunmaya açıktır.

Popüler masalların sinema uyarlamalarında kültürel antropolojik sürekliliği ile dönüşümünü inceleyen Tunalı'ya göre, masallardan sinemaya yapılan bağımsız uyarlamalarda, benzer bir biçimde metinlerarası bir açılım bulunmaktadır (Tunalı, 2017, s. 362). Bu bağlamda, masalların güncel sinemada yapılan pek çok uyarlaması, hem orijinal veya klasikleşmiş öncül metinlerle, hem de aynı film içinde farklı masalların birbiri arasında kurulacak şekilde metinlerarası ilişkilerle örülüdür.

“Bu bağlamda, günümüze filmler aracılığıyla uzanan masallar özellikle popüler Hollywood versiyonlarındaki haliyle, aristokratik bir zevkin domestik yaklaşımları olarak değiştirilmiş, daha önce söz ettiğimiz tehlikeli arkaik izler kısmen ortadan kaldırılmıştır. (...) Dönüştürülen karakterler, yan öyküler ve oluşturulan atmosferle birlikte kaynağını aldığı masaldan uzaklaşarak birkaç masala aynı anda gönderme yapan metinlerarası bir yapı kazanır" (Tunall, 2017, s. 369).

Bugün çağdaş anaakım sinemanın yeniden uyarladığı masallar, aslında sözlü kültürden yazılı kültüre belirli bir dönem ve toplumsal anlayışın egemen değerleriyle yeniden yazılmış metinleri kaynağına alarak tartışmaya açmış görünmektedir. Bu uyarlamalarda ilk göze çarpan alanyazındaki pek çok akademik araştırmanın da merkezinde bulunan, kadın ve erkek karakterlerin toplumsal cinsiyet rollerini gündeme getiren dönüşümler olmuştur. Bununla birlikte sadece kadın veya erkek karakter arketipleri değil, olay arketiplerinde de dönüşümler veya yeniden kurgulama girişimleri incelenmeye açıktır. 


\section{Sınırdaki Soruşturmalar olarak Postmodern Masal}

Postmodern metinlerin bir niteliği olarak metinlerarasılık, metinlerin arasında bulunan sınırlardaki keskinliği muğlaklaştıran soruşturmaları gündeme getirir. Hutcheon Postmodernizmi Kuramsallaştırmaya Başlamak adlı eserinde, postmodern kurmacayı öncelikli olarak kendini diğer çağdaş pratiklerden bilincinde olduğu çelişkiler, parodik metinlerarasılık ve tarihselcilikle çatışmalı bir diyalog yoluyla ayıran Avrupalı ve Amerikalı bir kültürel girişim olarak okur. Hutcheon'a göre, postmodern kurmaca "sınırların-deneyimi-olarak-yazma"nın uygulandığı, türler arasındaki sınırların aşıldığı ve "sanat ve düşün alanında tarihin rolünü görmezden gelen bir öznellik ve yaratıcılık tanımı" ile mücadele eden, sınırdaki soruşturmalar olarak tanımlanır (Bacchilega, 1997, s. 20).

Bacchilega'ya göre, sınırdaki soruşturmalar olarak geleneksel anlatıların postmodern revizyonları bu anlatıları okumamızı başkalaştırmaktan fazlasını yapar. Meta-folklor gibi, önceki yorumları için ideolojik bir test teşkil eder ve bunu yaparak, postmodern masallar, modern insanın kreş seviyesine indirdiği halk hikayesinin nasıl, neredeyse kinci bir şekilde bilinçaltımızı şekillendirdiği ve "gizlice hikâyede yaşadığı" hakkında bir farkındalık ortaya koyar (Benjamin'den akt.; Bacchilega, 1997, s. 22).

“(...) bu iyi düzenlenmiş hile alımlayıcının arzusunu öykünün yeniden tekrarı yönünde ürettiğinden beri, karşı-öykü öyküye içkindir: Tekrar, öykünün içinde güvence olarak işler, fakat bu aynı öyküyü tekrarlama dürtüsü iyi düzenlenmiş hile olarak masalın tutarlıı̆ı̆ı infilak / imha ettirir" (Bacchilega, 1997, s. 22).

Lyotard, postmodern fab/ terimini önerir ve fablın dilsel enerjisinin hayal etme için harcandığını belirtir: "Böylece, (fabl) bir gerçeklik üretir, bu öykünün gerçekliğidir, fakat bu gerçeklik bilişsel ve teknik kullanımına bağlı olarak askıya alınır (...) Bu askıya alma poetikayı pratikten ve pragmatikten ayırır (Lyotard, 1997, s. 95).

"Duyduğumuz fabl ne yenidir ne de orijinal. Ama postmoderndir. Postmodern yeni anlamına gelmez. Düşüncenin ve eylemin en geniş anlamı içinde, yazının nasıl modernitenin yaygınlaşmasına yenik düştükten sonra konumlandırıldığını ve kendini nasıl tedavi etmeye çalıştığını gösterir" (Lyotard, 1997, s. 96).

Lyotard'a göre, postmodern fabl, modern büyük anlatmın niteliklerini gösteremez, iyinin ve kötünün ayırdını yapamaz ve öykü için bir son tasarlamaz. Sona sahip olmayan öykünün yarattığı sıkıntılı durum zihnin ulaştığı postmodern bir durumdur. Modernite bunu kriz, hastalık veya melankoli olarak 
tanımlar. Fabl buna iyileştirici bir reçete sunmaz, buna bir açıklama getirir sadece. Bu açıklama ise ne bir meşrulaştırma ne de mahkûm etmektir (Lyotard, 1997, s. 100). Örneğin; "postmodern prenses anlatılarında, bu "yeniden paketleme" işlemi, anlatılardaki çok katmanlıık, parodi, ironi ve anlatı kahramanlarının belirsizliğiyle gerçekleşir. Örneğin klasik dönemdeki "iyi" ve "kötü" kadın temsilindeki netliğe postmodern prenses anlatılarında rastlanmaz" (Bostan \& Kırel, 2018, s. 12). Bununla birlikte sinemada pek çok masal uyarlamasında özellikle kadın karakterlerin dönüşümü toplumsal cinsiyet bağlamında özgürleştirici müdahaleleri akla getirirken, yine aynı uyarlamalarda dokunulmayan ve klasik yapısını koruyan pek çok karakter ve olay birimi yer almaya devam eder. Dolayısıyla hangi niteliğin dönüştürüleceği, hangisinin yerinde kalacağı temelde belirli bir söylemi inşa eder. Bu söyleme ulaşabilmenin ilk aşaması metnin -bu analiz kapsamında Sihirli Orman filminin- temel karakter ve olay arketiplerinin çözümlenmesinden geçer.

\section{Masalların Mite Dayalı Kökenleri ve Arketipler}

Postmodern uyarlama stratejilerinin önemli bir bölümünün masal karakter ve olay arketipleri üzerinde işlediğini kabul edersek metnin içerdiği farklı masal karakterleri ile olayların akışının incelenmesi önem kazanır. Masal metinlerinde yer alan bu karakter ve olay arketipleri köklerini mitlerden alır. “Mitlerdeki kişilerin genellikle Tanrılar ve Doğaüstü Varlıklar, masallardakininse olağanüstü kahramanlar ve hayvanlar olmasına karşıık, bütün bu kişilerin ortak bir yanı vardır: Onlar gündelik yaşamın bir parçası değildirler" (Eliade, 2016, s. 23). Fakat bu ortak yöne karşın, Eliade, eski topluluklarda insanların bu ikisi arasında yaptıkları ayrımı da vurgular: Mitler doğrudan doğruya kendi varlıklarını açıklayan gerçek öyküleri anlatırken, yalancı öyküler olarak masallar insanlığın durumunu değiştiren gerçek öyküler aktarmazlar. Ayrıca yalan(cı) öyküler her zaman ve her yerde anlatılabilirken, mitler topluluk tarafından kutsal olarak kabul edilen bir zaman süresince (genelde sonbahar ve kışın sadece geceleyin) ezberden söylenirler (Eliade, 2016, s. 22).

"Propp, halk masallarında, totemlere ilişkin inisiyasyon ritlerinin anısını bulur" (Eliade, 2016, s. 257). Masal, Eliade'a göre, tarihsel-kültürel bir bağlama değil, daha çok psikenin tarih dışı ve arketipe özgü bir davranışı dile getirdiğini belirtmenin önemini vurgular (2016, s. 257). Propp'un (2008) Rus masalları incelemesinden yola çıkarak ulaştığı 31 işlev, aynı zamanda birbirinden farklı yer ve zamanda, farklı ağızlarda anlatılmış olan farklı masal metinlerinin ortak olay birimlerini ortaya koyar. 
"Olağanüstü masallardaki kişilerin görünüş, yaş, cinsiyet, uğraş, medeni durum ile daha başka dural ve niteliksel özellikler açısından çok farklı olmakla birlikte, eylem süresince aynı edimleri yerine getirdikleri gözlemlenebilir. Bu da değişmeyen öğeler ile değiş̧en öğeler arasındaki bağıntıyı belirler. Kişilerin işlevleri değişmeyen öğeleri simgeler; bütün geri kalansa değişebilir (...)" (Propp, 2008, s. 152).

Masalların ulusal sınırların ve dillerin de ötesine varan ortak birimleri, insan toplumlarının kolektif bilinçdışı fikrini gündeme getirir. Örneğin Freud, psikanalizin sadece bireylere değil, toplumlara, özellikle de sanat eserleri ile mitsel alana uygulanabileceğini düşünmüştür. Bununla birlikte mitler, kökenlerini düşler gibi bilinçdışının derinliklerinden alsa da düşler gibi birer uyku ürünü değildirler (Sayılgan, 2014, s. 37). Jung, her ne kadar özel bir tanrı ya da tinsel bir güç iddiasında bulunmasa da bütün insanlığın metafizik bir düzeyde bağlantılı olduğuna ve bu metafizik ilişsinin din, inanç, tinsellikten daha büyük bir güce inanış yönündeki evrensel gereksinimin ardındaki psikolojik güç olduğuna inanmıştır.

Jung bütün insanlar arasındaki bu metafizik bağlantıya -bütün insanlar tarafından kolektif olarak paylaşılan bilincin bu alanındaki malzeme olarak - kolektif bilinçdışı adını vermiştir (Jung'dan akt. Indick, 2007, s. 105; Sayılgan, 2014, s. 37). "Düş kişiselleştirilmiş mittir, mit kişisellikten çıkarılmış düştür" (Campbell, 2010, s. 30). Toplumların gördükleri düşler olan mitler masallar ile aynı kökenden gelen arketiplere dayanmaktadır. "Yinelenen imge, simge, model ya da evrensel deneyimleri tanımlayan 'arketip' kavramı, sözcük olarak 'ilk örnek' ya da 'ilk imge' anlamına gelir" (Tecimer, 2006, s. 93).

Jung mitler ve masallarda karşılaşılan karakterleri sınıflandırmış ve persona, gölge, anima / animus ve akıl hocası gibi karakter arketiplerini tanımlamıştır. Buna göre, macera yolculuğuna çıkan bir kahraman arketipi bu yolculukta tek başına değildir. Onu yolculuğu boyunca izleyecek, ona engeller çıkaracak veya ona yardım edecek veya yön gösterecek başka karakterlerle karşılaşacaktır. Kolektif bilinçdışı yaklaşımı sadece kahraman arketipinin değil, ona eşlik eden tüm temel arketiplerin içerikten bağımsız bir şekilde farklı kültürler ve dillerde yinelendiğini ifade eder.

Freud ve Jung'un yaklaşımlarından yola çıkan Campbell ise arketiplerin sadece karakterlerle sınırlı olmadığını, bu karakterlerin başından geçen olay birimlerinin de arketipik olduğunu ortaya koyar. Campbell yinelenen olay örgüleri ve birimlerinin oluşturduğu yapıya monomitos adını verir: "Monomitos teriminden yola çıkarak olay ve yer bakımından çeşitlilik gösterseler de dünya üzerindeki tüm mitosların (ve dolayısıyla ritusların) tek ve aynı öykünün değişik görünümleri olduğunu belirtir (Tecimer, 2006, s. 107; Sayılgan, 2014, s. 41). Kahraman arketipinin başından geçen olay birimlerini ve olay örgüsünü 
modelleştiren Campbell Kahramanın yolculuğınun yapısını çözümler ve bu yolculuğun sözdizimini çizgisel değil fakat döngüsel bir formda sunar. Buna göre, kahraman öyküsünün başladığı noktaya değişmiş, dönüşmüş ve ders almış olarak; başka bir ifade ile erginlenmiş (inisiye olmuş) olarak geri döner. Campbell'a göre, "Peri masalının, mitin ve ruhun ilahi komedyasının mutlu sonu, bir çelişki olarak değil, insanın evrensel trajedisinin aşılması olarak okunmalıdır" (Campbell, 2010, s. 40).

Karakter ve olay arketipleri binlerce yıllık mit ve masal evreninin klasik biçimlerini üretmiş ve bugün hala sinema filmlerinden dijital oyunlara kadar uzanan öykü evrenlerinde temel işlev gören birimler olarak yer almaktadır. Bu klasikleşmiş metinlere postmodern müdahalelerin bir bölümü de mutlaka söz konusu karakter ve olay arketipleri üzerinde olacaktır. Bu araştırmanın odağında, Sihirli Orman filmi örneği üzerinden karakter ve olay arketiplerine nasıl ve hangi yöntemler ile müdahale edildiği, hangi dönüştürme ve bozuntuya uğratma pratiklerine başvurulduğu ve hatta hangilerinin dışarıda bırakılarak metinde sürdürüldüğüne bağlı olarak izlenen söz konusu postmodern stratejilerin üretmiş olduğu anlatısal söylem yer almaktadır.

\section{YÖNTEM}

Bu araştırmanın örneklemi olan Sihirli Orman filminin analizi iki aşamadan oluşmaktadır. İlk aşamada postmodern dönüşümlerin hangi karakter ve olay arketiplerinde uygulandığını çözümleyebilmek amacıyla Campbell'in monomitos modelinden yola çıkılarak filmin yapısal analizi yapılmıştır. İkinci aşamada, Gérard Genette'in "Anlatının Söylemi: Yöntem Hakkında Bir Deneme" adlı eserinde geliştirmiş olduğu, anlatı ve söylem arasındaki ilişkiyi ortaya koymaya imkân veren çözümleme yöntemi kullanıımıştır.

Anlatının yapısal analizi, anlatının söylem analizinin yapılması için gerekli olan verilerin sağlanması açısından önemli bir ilk aşamadır. Sihirli Orman filminin olay örgüsü ve arketiplerin postmodern dönüşümleri, Campbell'ın olay arketipleri sınıflandırmasına (bkz. Tablo 1) göre haritalandırılmıştır (bkz. Tablo 3).

Campbell'ın yaklaşımında, olay birimlerinin oluşturduğu arketipik yolculuğun üç temel aşamasını Yola çıkış, Erginlenme ve Dönüş eşikleri birbirinden ayırmaktadır. Her aşama kendi içinde alt birimlerin sözdiziminden oluşur. Döngüyü oluşturan eşikler kahramanın normal ve sıradan yaşamından olağanüstü olayların yaşanacağı özel bir dünyaya geçmesi, fakat sınavlar yolunun da içinde bulunduğu erginlenme 
sürecini tamamladıktan sonra tekrar normal ve sıradan dünyaya geri dönmesini esas alır. Sihirli Orman filminin içinde karmaşık bir biçimde yer alan tüm masal metinleri birbiri ile ilişkisi içinde Campbell'ın olay arketipleri kategorilerinden yola çıkılarak çözümlenmiş, böylece söylem analizine tabi tutulacak hikâye, anlatım ve metin nitelikleri ortaya konabilmiştir.

Tablo 1 Campbell'ın Kahramanın Sonsuz Yolculuğu (2010)'dan yola çıkılarak oluşturulmuş olay arketipleri tablosu (Campbell, 2010)

\begin{tabular}{lll}
\hline YOLA ÇıKıŞ & ERGiNLENME & DöNüş \\
\hline Maceraya çağıı & Sınavlar yolu & Dönüşün reddedilmesi \\
Çağrının reddedilmesi & Tanrıçayla karşılaşma & Büyülü kaçış \\
Doğaüstü yardım & Baştan çıkarıcı kadın & Dışarıdan gelen kurtuluş \\
illk eşiğin aşılması & Babanın gönlünü alma & Dönüş eşiğinin aşılması \\
Balinanın karnı & Tanrılaştırma & iki dünyanın ustası \\
& Nihai ödül & Yaşama özgürlüğü \\
\hline
\end{tabular}

Genette, Anlatının Söylemiadlı eserinde, anlatı çözümlemesini beş kategori üzerinden inceler: Kip, ses, düzen, sıklık ve süre (Dervişcemaloğlu, 2017, s. 1-11).

Kip: "Bir metin kaleme alınırken, onun sözel takdimiyle ilgili teknik tercihler yapılarak belirli bir anlatı kipi yaratııır. Genette'e göre bütün anlatılar, kaçınılmaz bir biçimde "diegesis"tir." Buna göre yazar, hikâyesini gerçekçi ve yaşanmış gibi göstermeye çalışsa da, bir mimesis ilüzyonu yaratmaktan öteye gidemez (Dervişcemaloğlu, 2007, s. 1-2). Genette'in kip kategorisi alt kategorilere ayırarak anlatının söylemini inşa eden unsurlara mercek tutar;

Tablo 2 Gérarad Genette'in Anlatı Kuramına göre Kip Kategorileri (Dervişcemaloğlu, 2007, s. 2-6)

\begin{tabular}{|c|c|c|c|}
\hline MESAFE & ANLATICININ IŞLEVLERI & ANLATI PERSPEKTIFI & ODAKLANMA \\
\hline a) Anlatılan Konuşma & a) Anlatma Işslevi & $\begin{array}{l}\text { a) Her Şeyi Bilen Anlatıcı } \\
\text { Konumu }\end{array}$ & a) Sıfır Odaklanma \\
\hline b) Dolaylı Söylem & b) Yönlendirme İşlevi & b) Ben Anlatım Konumu & $\begin{array}{l}\text { b) İçsel Odaklanma } \\
\text { c)Dışsal Odaklanma }\end{array}$ \\
\hline $\begin{array}{l}\text { c) Serbest Dolaylı } \\
\text { Söylem }\end{array}$ & c) Bildirişim İşlevi & c) Kişisel Anlatım Konumu & \\
\hline d) Dolaysız Söylem & $\begin{array}{l}\text { d) Doğrulama İşlevi } \\
\text { e) İdeolojik İşlev }\end{array}$ & & \\
\hline
\end{tabular}

Ses: Genette, bu kategoriyi kişi, anlatma zamanı ve anlatı düzeyi alt başlıklarına ayırır. Böylece anlatııının hikâyedeki varlığı, hangi zaman kipiyle anlattığı ve hikâye düzeyleriyle ilişkisi ortaya konulurken anlatıda konuşan sesin eylemlerle olan ilişkisini de belirlemek mümkün hale gelir (Evecen \& Can, 2017, s. 288). 
Düzen: Olayların anlatıda nasıl sıralandığıyla ilgilidir. Bir anlatıcı, olayları kronolojik olarak sunmayı seçebilir ya da bu sıraya uymadan anlatabilir. Genette, kronolojik olmayan düzeni anakroni terimiyle ifade eder ve iki çeşit anakroni olduğunu belirtir:

“Analepsis: Anlatıcı, önceden olmuş bir olayı ya da olayları anlatır.

Prolepsis: Anlatıcı, ana öykü bittikten sonra olacak olayları haber verir." (Dervişcemaloğlu, 2007, 5. 9)

Sıklık: Bir olayın hikâyede kaç kere meydana geldiğiyle, anlatıda kaç kere zikredildiği arasındaki ilişkidir. Genette'e göre burada önemli olan iki nokta vardır: Olayın tekrarlanıp tekrarlanmaması ve ifadenin tekrarlanıp tekrarlanmaması (Dervişcemaloğlu, 2007, s. 10).

Süre: Genette süre ile anlatının hızını kastetmektedir. Yazarlar anlatının hızını değiştirerek okuyucu üzerinde istedikleri etkiyi yaratabilirler. "Genette'e göre dört tip anlatı hızı vardır: Duraklama: Olayın kesilmesidir. Sahne: Anlatı zamanı ile öykü zamanı aynıdır. Özet: Anlatıdaki olayın bir kısmı özetlenir, böylece hız arttırılır. Eksilti: Anlatıda bazı olaylar hakkında hiçbir şey söylenmez yani o kısımlar atlanır." (Dervişcemaloğlu, 2007, s. 10)

Genette'in roman anlatılarına yönelik olarak kurmuş olduğu bu çözümleme yönteminin sinematografik anlatılara doğrudan uygulanması kolay değildir. Bir anlatı olarak filmsel metinler ile yazınsal metinler arasındaki farklııklar Genette'in analiz değişkenlerinin bir film çözümlenmesi için yeniden uyarlanması gereğini doğurur. Genette'in yöntemini sinematografik anlatıların çözümlenmesi için yeniden düzenleyen bir dizi araştırmacı, her iki kurmaca yapıda benzerlikler taşıyan; olaylar, olayların yinelenmesi, olay örgüsü, kişiler ve kişileştirme gibi unsurları temel alırlar (Sözen, 2008, s. 168). Bu çalışmada, Genette'in analiz değişkenlerini filmsel metinlere göre yeniden düzenleyen Edgar-Hunt, Marland ve Rawle'in kategorilendirmesi temel alınmıştır:

\section{" Hikâye (içerik)}

$\begin{array}{lc}\text { Olaylar } & \text { kronoloji/nedensellik } \\ \text { Karakterler } & \text { eylemler/etkileşimler } \\ \text { Ortam } & \text { zaman/mekânsal bileşikler }\end{array}$

\section{Anlatım (söyleme)}

$\begin{array}{ll}\text { Tipler } & \text { güvenilir/güvenilmez } \\ \text { Düzeyler } & \text { iliştirilmiş/anlatım }\end{array}$


Ses

anlatıcı/karakter

\section{Metin (sunum)}
Zaman
düzen/süre/sıklık
Karakterizasyon
kişilik özellikleri/nitelikler
Odaklanma
olayları kim görüyor/algllıyor/yargllıyor" (Hunt,

Marland, \& Rawle, 2015, s. 54).

Bu kategorilerden yola çıkılarak, Sihirli Orman filminin Campbell'ın monomitos kavramsallaştırması bağlamında ortaya konmuş olan yapısı çözümlenmiş, ikinci aşamada anlatının söylem analizi yapılmıştır.

\section{BULGULAR VE TARTIŞMA}

\section{Aşama: Sihirli Orman Filmi Anlatı Çözümlemesi}

Sihirli Orman filmi anlatı çözümlemesi Campbell'ın Kahramanın yolculuğu yaklaşımından ortaya koyduğu döngüsel monomitos kuramının kategorilerden yola çıkılarak ve metinlerarası-postmodern dönüşüm ve müdahaleleri bulgulamak amacı ile gerçekleştirilmiştir. Dört farklı masala ait olay ve karakterleri karmaşık bir biçimde bir araya getiren filmin söylemi ilk bakışta bulanık görünmektedir. Filmin feminist perspektife mi yerleştiği, postmodern bir metin olarak mesajı silikleştirirken neyi öne çıkarıp hangi söyleme yaklaştığı ve bir mesajı olup olmadığını ilk bakışta belirtmek mümkün olmamaktadır. Tam da buradan yola çıkılarak, araştırmanın ilk aşamasında klasik masal metinlerinin çözümlenmesinde önerilen bir yaklaşım olarak monomitos metnin akışını ve söylem analizine tabi tutulacak yapısını kristalize ederek ortaya çıkarmakta işlev görmüştür. Tablo 3'te de görüldüğü gibi farklı olay ve karakter arketiplerinin akışı modelde yer alan temel eşik kategorileri (Yola Çıkış- Erginlenme- Dönüş) esas alınarak sınıflandırılmıştır:

Tablo 3 Sihirli Orman (Into The Woods) Anlatısının Kahramanın Yolculuğu Modeli Bağlamında Çözümlenmesi

\begin{tabular}{|c|c|c|c|}
\hline AŞAMA & Eşik & NE ISTIYOR? & Külkedisi baloya gitmek istiyor. \\
\hline & Yola Çıkış & & Jack ineğinden ayrılmamak istiyor. \\
\hline & Maceraya Çağıı / & & \\
\hline & Çağrının Reddi & & \\
\hline & & & Fırıncı ve karısı çocuk sahibi olmak \\
\hline & & & istiyor. \\
\hline & & & Kırmızı Başlıkıı Kız büyükannesine \\
\hline & & & gitmek istiyor. \\
\hline
\end{tabular}




\begin{tabular}{|c|c|c|c|c|}
\hline Ormana giriş & $\begin{array}{l}\text { Yola Çıkış } \\
\text { Doğa üstü yardım } \\
\text { /ilk eşik }\end{array}$ & Ormana girmek & $\begin{array}{l}\text { Kırmızı Başlıklı Kız ormana ilk giren } \\
\text { karakter oluyor }\end{array}$ & \\
\hline & & & $\begin{array}{l}\text { Jack annesinin isteğiyle süt vermeyen } \\
\text { ineği satmak için gideceği komşu köye } \\
\text { ormandan geçerek gidecek. } \\
\text { Fırıncı ve karısı Cadı́nın verdiği görev } \\
\text { (iksir) için giriyor. } \\
\text {-iksir için; } \\
\text { 1-Beyaz bir inek (süt gibi) } \\
\text { 2-Kırmızı bir pelerin (kan gibi) } \\
\text { 3-Sarı saç (mısır püskülü gibi) } \\
\text { 4-Ayakkabı (altın gibi saf) } \\
\text { Külkedisi annesinin mezarına gidiyor. } \\
\text { Baloya gitmek için dua ediyor. }\end{array}$ & $\begin{array}{l}\text { Erkeğin görevi } \\
\text { mi, kadın da } \\
\text { girmeli mi } \\
\text { ormana? }(F)^{1}\end{array}$ \\
\hline $\begin{array}{l}\text { Ormanda ilk } \\
\text { karşılaşma ve } \\
\text { maceraya } \\
\text { kabul }\end{array}$ & $\begin{array}{l}\text { Yola Çıkış } \\
\text { Balinanın karnı }\end{array}$ & & $\begin{array}{l}\text { Külkedisi maceraya atıımak üzere } \\
\text { annesinden (peri, ilahi yardımcı, } \\
\text { tanrıça'dan) balo elbisesini ve altın } \\
\text { ayakkabılarını alıyor. } \\
\text { Kırmızı Başlıklı Kız kurtla karşılaşıyor. } \\
\text { Fırıncı Kırmızı Başlıklı Kız'la karşılaşıyor. } \\
\text { Fakat pelerini alamıyor. } \\
\text { Daha sonra fırıncı Kırmızı Başlıkıı Kız'ı } \\
\text { kurttan kurtarınca kız ona pelerinini } \\
\text { hediye veriyor. } \\
\text { Fırıncı ve karısı Jack'e fasulye veriyorlar. } \\
\text { Beyaz ineği alıyorlar }\end{array}$ & İnek (+) \\
\hline ilk gece & $\begin{array}{l}\text { Erginlenme } \\
\text { Sınavlar yolu }\end{array}$ & & $\begin{array}{l}\text { Jack'in annesi evin önünde sinirle } \\
\text { fasulyeleri atıyor, fasulye sırığı büyüyor. } \\
\text { Külkedisi gece saraydan koşarak } \\
\text { kaçıyor. Fakat büyü bozulacağı için değil, } \\
\text { prensten o kadar da etkilenmediği için. } \\
\text { Fırıncının karısı Külkedisi'nin } \\
\text { ayakkabısını alamıyor. İnek kayboluyor. }\end{array}$ & $\begin{array}{l}\text { Külkedisi } \\
\text { dileğini ilk kez } \\
\text { sorguluyor. (F) } \\
\text { İnek (-) }\end{array}$ \\
\hline Ertesi sabah & & & $\begin{array}{l}\text { Jack fasulye sırığından çıkıp devler } \\
\text { ülkesinden altın çalarak ormana giriyor. } \\
\text { Amacı ineğini geri almak. }\end{array}$ & \\
\hline
\end{tabular}

${ }^{1}$ (F) simgesi, çözümleme içinde feminist perspektiften yapılan postmodern dönüşüm girişimlerini vurgulamaktadır.

${ }^{2}$ (+) ve (-) simgeleri, Cadı tarafından Fırıncı ve Karısına bulmaları için verilen görev-nesnelerin hikâyeye giriş ve çıkışlarını kontrol etme işlevi için kullanılmıştır. 
2. Gece

2. Sabah

3. Gece

İksire 1.Nihai Ödül

kavuşma
3. Sabah
1. Dönüş

$\begin{array}{ll}\text { Tekrar } & \text { 2.Erginlenme } \\ \text { ormana kaçış } & \text { Sınavlar yolu } \\ \text { / sığınma } & \end{array}$

2 prens ormanda karşılaşıyor.

(Külkedisi'ni arayan ve Rapunzel'e âşık

olan)

Fırıncının karısı Rapunzel'in saçını kesip Saç (+)

alıyor.

Külkedisi yine prensten kaçıyor.

Ayakkabısını bırakmıyor.

Fırıncı karısının ormanda yanında

kalmasına izin veriyor.

İnek ölüyor.

Fırıncı parayla yeni inek almaya karar

veriyor.

Jack altın yumurtayla yine geliyor.

Jack Kırmızı Başııııı Kız'la karşılaşıyor.

Kız artık kurt kürkünden pelerin giyiyor.

Elinde bıçak taşıyor ve kimseye çabuk

inanmıyor.

Jack sırığı kesip devi düşürerek

öldürüyor.

Rapunzel'in prensi Cadı'ya yakalanıyor.

Cadı prensi kör edip, kızının saçını

kesiyor.

Külkedisi yine prensten kaçıyor.

Ayakkabı (+)

Ayakkabısını bilerek bırakıyor, diğerini de

fırıncının karısına veriyor

Prens Külkedisini sonra buluyor.

Cadı ineği büyüyle canlandırıyor.

Cadı fırıncının ve karısı için iksiri

hazırlıyor.

Amaçlar için

birlikte

çalışmalıyız (F)

Inek (+)

Kırmızı Başıkılı

Kız yeniden

masala giriyor.

Rapunzel sevgilisi prense kavuşuyor ve gözyaşlarıyla büyüyü bozuyor. Prensin gözleri açılıyor.

Bütün masallar mutlu sonla bitiyor.

Külkedisi prensle, Rapunzel diğer

prensle evleniyor. Jack ve annesi zengin

olmuş; fırıncı ve karısının ise çocukları

kucağında.

Bu sırada ölen devin karısı dünyaya inip krallığa saldırıyor. Jack'i arıyor.

Fırıncı ve karısı amaçlarına

ulaşıyorlar.
Ormana 2. giriş Yeni amaçlar: Jack'i korumak Hayatta kalmak
Fakat orman değişmiş,
Orman bildikleri orman değil artık ve yollarını kaybediyorlar.
Yeni amaçları var.


Deve karşı birlikte

savaşmak

Fırıncının karısı ve Külkedisi'nin prensi ormanda karşılaşıyor ve aralarında bir çekim oluyor. Öpüşüyorlar. Bundan sonra fırıncının karısı bir çukura düşüp ölüyor.

Fırıncı bebekle ve diğerleriyle kalıyor. Bebeğe bakamayacağını söylüyor tek başına. Fakat sonunda bir baba olarak bebeğe tek başına bakabilmeyi kabulleniyor.

(ortak amaç: birlikte hareket etmek)
Birbirlerini suçlama

Cadının masalı terk etmesi

Hep birlikte deve karşı birleşerek savaşma

Külkedisi Prensle gitmiyor: "Babamın evi kabusken, seninki rüyaydı. Ben ikisi arasında bir şey istiyorum". Jack'in annesi ölüyor. Kımızı Başlıklı Kız da yalnız kalıyor. Çocuklar artık kendileri karar vermeli, gerekirse hata da yapmalılar: "Cadılar haklı, devler iyi olabilir, kendin karar ver buna".

Birlikte devi yeniyorlar.

Fırıncı artık eve gidebiliriz, diyor.

Hepsi: "Ne evi? Evimiz yok artık."

Fırıncı, Külkedisi, Jack ve Kırmızı Başlıklı Kız birlikte gidiyor.

Külkedisi: "Temizlik yapmayı sevdiğim zamanlar da vardı".
Rapunzel ile prensi

masaldan çıııyorlar. (kaçıyorlar) Fırıncının karısı masaladan çıkıyor (F) Kocasıyla olan ilişkisini unutup başka bir adamla öpüştükten hemen sonra dengesini kaybedip çukura düşüyor.

Erkek toplumsal cinsiyet rolleri

(F).
(F) Prenses olmak istemiyor. 
Fırıncı oğluna hem anne hem de baba olmayı kabul ediyor.

Jack ve Kırmızı Başlıklı Kız da artık anneleri olmadan yaşamalı kendi kararlarını verebilmeliler.
(F). Babası gibi olmamak, kendi kaderini kendi çizmek. Masalda biçilen alınyazısını değiştirmek Çocukluktan çıkış, inisiyasyon.

Tablo 3'ten de izlenebileceği gibi, Sihirli Orman filmi temel eşiklere sahip olmakla birlikte "tekrar ormana kaçış / sığınma" aşaması ile öyküye postmodern bir eklenti ile sürdürülmüştür. Bu ek sekans klasik kapanışı yeniden açarak, yeni sorgulamaları gündeme getirmektedir. Buna karşın öykü yeni bir kapanış ile klasik döngüyü ikinci bir kez için tamamlayacak şekilde biter. Tüm masal kahramanları eşiklerin sağladığı izleklerden geçmekte, sadece bir yan karaktere dönüşen Rapunzel 2. erginlenmeye girmeden ormandan kaçmaktadır.

Bireysel "mutlu son", postmodern eklenti ile "ortak amaca" dönüşür. Gökyüzünden aniden inen ortak bir düşmana karşı hep birlikte mücadele edilir. Hayatta kalan ve merkezi konuma yerleşen dört "kahraman" (Külkedisi, Fırıncı, Kırmızı Başlıklı Kız ve Jack) Fırıncı'nın etrafında dönüşmüş olarak son eşiğe ulaşabilir.

\section{Aşama: Sihirli Orman Filmi Anlatısının Söylem Çözümlemesi}

\section{Hikâye (içerik)}

Yönetmenliği Rob Marshall'ın yaptığı Sihirli Orman filmi Kırmızı Başlıkı Kız, Külkedisi, Jack ve Fasulye Sırı̆̆ı, Rapunze/masallarının kahramanlarının yollarının ve hikâyelerinin kesişmesini konu edinir.

Olaylar: Filmin olay örgüsü incelendiğinde; tüm kahramanların sıradan yaşamından ormana olağanüstü olayların yaşanacağı özel dünyaya- girişiyle başlayan yolculuklarının, arketipik yolculuğun üç temel aşamasını Yola çıkıs̆, Erginlenme ve Dönüş eşiklerini içerdiği görülür ${ }^{3}$. Farklı istençlerin peşinden yola çıkan farklı masalların kahramanlarının ormanda yollarının kesişmesiyle klasik masal anlatı döngüsü kırılarak metinlerarası ilişkiler kurulur. Dört masalın kahramanlarının birbirlerinin amacı, engeli, sınavı ve sonucu oldukları bir nedensellik ilişkisiyle kurulan filmin olay örgüsünde masalların her biri filmin ana

\footnotetext{
${ }^{3}$ Bknz. Tablo 3 Sihirli Orman (Into The Woods) anlatısının Kahramanın Yolculuğu modeli bağlamında çözümlenmesi
} 
hikâyesine hizmet eden yan hikâyelerdir. Filmin ana hikâyesi Fırıncı ve Karısının hikâyesidir. Klasik masallardaki yan karakterleri ana kahramanlar olarak, ana kahramanları ise birer yan karakter olarak (Külkedisi, Kırmızı Başlıklı Kız, Jack vd.) sunan film bu bağlamda yapısökümcü bir metin olarak karşımıza çıkar. Olayları ilerleyiş̧i ile birlikte dönüştürülen karakterler, yan öyküler ve oluşturulan atmosferle kaynağını aldığı birkaç masala aynı anda gönderme yapan film, metinlerarası bir yapı kazanır.

Kahramanların arketipinin başından geçen olay birimlerini ve olay örgüsünü Campbell'ın Kahramanın yolculuğu yapısına göre çözümlediğimizde de bu yolculuğun çizgisel değil döngüsel bir formda sunulduğu ve kahramanların öykülerine başladıkları noktaya değişmiş, dönüşmüş ve ders almış olarak geri döndükleri görülür. Ancak bu döngüselliğin sonunda erişilen mutlu son filmin sonu değildir. Tüm masalların bir karakterinin ölmesinin ardından hayatta kalan masal karakterlerinin dört masalın sonuna alternatif bir son oluşturacak şekilde erginlenme sürecini yeni baştan yaşaması ile döngüsellik kirilir.

Karakterler: Külkedisi, Fırıncı ve Karısı, Cadı, Kırmızı Başlıklı Kız ve Jack aynı krallıkta yakın yerlerde yaşamaktadır. Tüm kahramanların bir arzusu/isteği vardır. Cadı üzerindeki laneti kaldırmak ve yeniden genç/güzel görünmek istemektedir, bunun için Fırıncı ve Karısına bir teklifte bulunur: Üç gece sonra gerçekleşecek olan mavi dolunaya kadar "süt kadar beyaz bir inek, kan kadar kırmızı bir pelerin, mısır püskülü kadar sarı bir saç ve altın kadar parlak bir ayakkabı" bulmaları halinde Cadı onların üzerindeki laneti kaldırarak çocuk sahibi olmalarını sağlayacaktır. Fırıncı ve Karısı verilen görevi yerine getirmek için ormana girerler. Prensin balosuna gitmek isteyen Külkedisi, ineğini satmak zorunda olan Jack ve Büyükannesini ziyaret etmek isteyen Kırmızı Başııkı Kız da ormana girerler. Ormanda üç gün üç gece boyunca yolları kesişen kahramanlar birbirlerine yardımcı olurlar ya da birinin isteği diğerinin isteğinin gerçekleşmesini engeller. Bazen de birbirlerine zarar verir, korkutur veya yoldan çıkarırlar. Sonunda ortaya çıkan ortak düşmanları için (fasulye sırığından inen Dev Kadın) birlikte hareket etmeleri gerekir. İlk başta Dev Kadının yere inmesi konusundan birbirlerini suçlarlar, her biri bir diğerinin arzularının buna neden olduğunu savunur. Bu süreçte Cadı, Jack'in annesi ve Fırıncının Karısı farklı sebeplerle ölür. Kalan kahramanlar birlikte hareket ederek Devi yenerler ve birlikte yaşayacakları evlerine doğru yola çıkarlar. Karakterler arasındaki bu etkileşim ve eylemlerinin birbirlerinin yolculuklarına olan etkisi anlatının söyleminin inşasında önemli bir rol oynar. Filmin sonunda verilen "kimse yalnız değildir" mesajını inşa etmek için oluşturulan bu ilişkiler ağı, klasik masal anlatılarından bu noktada da ayrılır. Sihirli Orman 
filminin en pasif ve ne istediğini bilmeyen karakterler olarak sunulan karakterlerinin filmin mesajını ileten kahramanlara dönüştürülmesi dikkat çekicidir. Pasif-güçsüz-tembel-akılsız vb. niteliklerle sunulan karakterlerin birlikte hareket etmesiyle elde ettikleri başarı ve hayatta kalmalarıyla sonlanan film, bu noktada klasikleşmiş metinlere karakter ve olay arketipleri üzerinden yapılan postmodern müdahalelere önemli bir örnek olma niteliği kazanır.

Karakterler arasındaki etkileşimin temel noktası, Fırıncı ve Karısının elde etmeye çalıştığı nesnelerin diğer masal kahramanlarına ait olması olsa da karakterlerin eylemlerinin gerçekleştiği tek mekân olan orman da anlatının içinde önemli bir etkileşim kaynağıdır.

Ortam: Filmin ana mekânı olan orman, tüm kahramanların amaçlarına ulaşmak için gitmeleri gereken yerdir. Ormana girerken her birinin tekrar ettiği şu cümle dikkat çeker: "Yol açık, ışık iyi, ne benim ne de başkasının korkusu olmalı... Orman sadece ağaçtır, ağaçlar ise odun. Ormandan korkmaya gerek yok!" Amaçlarına ulaşmak için yola çıkan karakterler ormanın tehlikeli bir yer olmadığına dair kendilerine telkinde bulunurlar, çünkü filmde sıklıkla tekrar edildiği üzere orman güvenli değildir. Peki, ormandaki tehdit/tehlike nedir? Ormanın neden tehlikeli olduğuna dair açık ve net bir bilgi verilmez ama tehditkâr bir mekân olarak aktarımanın yanında orman öyle de gösterilir: Ormanın içinde kuş sesi duyulmaz, güneş ışığı ağaçları aşıp yere ulaşamaz, karanlık, kasvetli bir havası vardır. Ormanın görselleştirilmesinde tercih edilen karanlık ve kasvetli hava, tüm hikâyenin günün aynı zaman diliminde yaşandığının düşünülmesine neden olur. Anlatıda zamanın akışı karakterlerin eylemleri ve etkileşimleri ile aktarılır. Her gece yarısında Külkedisi balodan kaçar, Cadı aniden ortaya çıkar ve Fırıncı ve Karısına görevi tamamlamak için ne kadar zamanları kaldığını söyler. Anlatıda ortamın bu biçimde yaratılmasının-aktarılmasının tercih edilmesi; ormanı kahramanlar için olduğu kadar izleyici için de belirsizliklerle dolu bir mekâna dönüştürür. Tüm bunların yanı sıra orman, karakterler tarafından isteklerine erişmelerine imkân veren ve ummadıkları bir anda yeni şeyler öğrenmelerini sağlayan bir ortam olarak da nitelenir. Ormanın sihri tam olarak burada yatmaktadır: Orman kahramanları değiştirir. Peki, filmde söylendiği gibi karakterlere bu değişimi bahşeden gerçekten ormanın sihri midir? Sihirli Orman filminde karakterler yaşadıkları dönüşümün/farkındalığın kaynağı olarak ormanın sihrine atıfta bulunsalar da erginlenmiş (inisiye olmuş) olarak geri dönmelerini sağlayan ana neden ormanda karşılaştıkları sorunlar/sınavlar ve diğer karakterlerle olan etkileşimleridir. 


\section{Anlatım (söyleme)}

Tipler: Filmde pek çok masalın asıl kahramanları arasında olan yakışıklı, çekici ve şık giyimli prensler arketipik özelliklere sahip gibi görünseler de korkak, sadakatsiz, zeki olmayan ve narsistik karakter özellikleri ile donatılmışlardır. Bu durum da onları güvenilir kişiler olmaktan oldukça uzaklaştırır. Prensin Kâhyası, Jack'in Annesi ve Rapunzel de diğer tipler olarak karşımıza çıkarlar. Tüm bu tipler tam da Genette'in belirttiği gibi aldatıcı davranışlar içerisinde olan, bu nedenle güvenilir olmayan aynı zamanda da filmin olay örgüsünü ilerletmeyen karakterlerdir (Hunt, Marland, \& Rawle, 2015, s. 55). Sihirli Orman filmdeki bu güvenilir olmayan karakterlerin söylemleri ve eylemleri, filmin anlatısında karakter arketiplerinin nasıl yerinden edildiğini ve bozuntuya uğratıldığını gösterir.

Kadın karakterler tarafından temsil edilmiş olan Prenses ve Cadı gibi birbiriyle çatışma içinde olan ve hikâyeyi ilerleten tipler en çok sorgulamaya açılan ve farklı olasılıkları gündeme getirilenler olmuştur. Bununla birlikte tipolojik niteliklerin muğlaklaştırılması postmodern metnin niteliğine dönüşür. "Kötü" cadı, aynı zamanda kızının güvenliğini düşünen "iyi" bir annedir; "aşık" prens aldatmaya hazırdır, "iyi kalpli" ve "güzel" prenses güvenilmez ve aklı karışıktır. Sihirli Orman bileşenlerinden, film içinde artık bir yan hikâye teşkil eden ve filmin 1. Dönüş eşiğinde mutlu sona ulaşarak son sekansına dahil olmayan Rapunzel (ve prensi) klasik tipolojileri dışına çıkmazken, merkeze alınan tüm tiplerin nitelikleri dönüşüme uğramış görünmektedir. Bu bağlamda kimin güvenilir, kimin güvenilmez olduğu da belirsiz ve değişken hale gelmiştir.

Düzeyler: Genette, anlatıların çözümlenmesinde "kim, ne zaman, nerede ve kiminle konuşuyor" sorularının oldukça önemli sorular olduğunu belirtir (Hunt, Marland, \& Rawle, 2015, s. 55). Sihirli Orman filminin anlatısında karakterler arasındaki eylemler kadar konuşmalarında da hikâyenin ve karakterizasyonun gelişiminde önemli bir rol oynadığı görülür. Film, anlatım konumlandırması açısından değerlendirildiğinde sinemada kullanılan üç anlatım biçiminin de kullanıldığı görülür; içöyküsel ${ }^{4}$ (örn. Fırıncı ve Karısı, Cadı ve Rapunzel arasında geçen konuşmalarla karakterizasyon gelişimi sağlanır), öyküsel $\left.\right|^{5}$ (Külkedisi merdivende neden prensten kaçtığına dair kendi düşüncelerini sorgular) ve dış

\footnotetext{
4" içöyküsel (intradiegetic): İki ya da daha fazla karakterin birbiriyle kendi menfaatleri için değil, hikâyenin ya da karakterizasyonun gelişimi için konuşmaları." (Hunt, Marland, \& Rawle, 2015, s. 55)

5 "Öyküsel (homodiegetic): Filmin bir karakterinin anlatıcı olması. Bir üst ses ya da nadiren kameraya bakarak konuşan biri." (Hunt, Marland, \& Rawle, 2015, s. 55)
} 
öyküsel ${ }^{6}$ (filmde yer alan dış ses-anlatıcı karakterler ve gerçekleşen olaylar ile ilgili bilgi verir) anlatım biçimini kullanılır. Sihirli Orman filminde bu düzeylerin işlemesi yanında, müzikal sahneleme kullanımı da hikâyenin akışı hakkında yönlendirme işlevi görür.

\section{Metin (sunum)}

Zaman: Bir anlatıda gördüğümüz şeylerin sıralaması ve ne kadar uzun sürdüğü filmin anlatısında nelere öncelik verildiğinin önemli bir göstergesidir. Sihirli Orman filminde olaylar kategorisinde de değinildiği üzere olaylar nedensellik üzerine kurulu ilişkiler ile sıralanır. Bu sıralama tercihi ile karakterlerin ilişkileri, eylemleri ve karakterlerin yaşadığı dönüşümlerin iç içe geçtiği bir yapı kurulur.

Bazı ortak temaların özellikle kadın kahramanların yer aldığı sahnelerde sıklıkla tekrarlandığı görülür. Bu sahnelere en iyiörneklerden biri Külkedisinin balodan kaçış sahneleridir. Filmde, balodan kaçış sahneleriyle klasik masalın asıl olay örgüsü parodileştirilerek masalların ataerkil söylemlerine feminist bir bakış açısıyla göndermede bulunulur. Külkedisi üç gece üstü üste balodan kaçar ve her seferinde Fırıncının Karısı ile karşılaşır. Bu karşılaşmalar Külkedisi için rahatsız edici olur ama aynı zamanda neden kaçtığına dair düşünmesine de zemin oluşturur. Son gece Prens merdivenlere zift döker ve Külkedisinin ayakkabıları yere yapışır. Külkedisi kendini kurtarır ancak Prensin onun için çabalaması hoşuna gider. Ne istediğinden emin olmayan ve karar vermenin zorluğu ile baş edemeyen Külkedisi, üçüncü gece kendi elleri ile ayakkabıyı ipucu olarak merdivene bırakır. Böylelikle Külkedisi kendi tercihlerini yapmak yerine Prensin kararına göre hareket etmeyi seçer. Bu teslimiyet onu klasik masal anlatısının mutlu sonuna götürse de aslında kendini ait hissetmediği bir yerde yaşamaya mahkûm olmasına neden olur. Saraydan kaçan Külkedisinin ormanda Prensle karşılaştığında söyledikleri tekrarlanan bu sahnelerin sonucudur: "Babamın evi bir kabustu, senin evinse bir rüya, arada bir şey istiyorum." Bu sözlerle filmin başından itibaren ne istediğini bilmeyen ve bu nedenle kendi hayatı ile ilgili karar veremeyen Külkedisi kendi yolunu çizebilecek bir karaktere dönüşür.

Filmde, Cadı ve Rapunzel arasında geçen anne-kız tartışmaları (dış dünyanın tehlikelerle dolu olması ve annenin çocuğunu koruma arzusunun çocuğun özgürlüklerini kısıtlaması), Fırıncı ve Karısı arasında geçen neredeyse tüm konuşmalarda (evlilikte kadın-erkek rolleri) hâkim olan toplumsal rollere

\footnotetext{
6 "Dışöyküsel (extradiegetic): Filmin öykü dünyası içerisinde olmayan ya da o aşamada karakterin kim olduğunu bilmediğimiz bir dış sesin hikâye anlatıcılığı yapması." (Hunt, Marland, \& Rawle, 2015, s. 55)
} 
ilişkin söylemlerin eleştirisi tekrarlanan sahnelerle anlatının söyleminde önemli bir rol oynar. Ayrıca bilinçli olarak seçilen kadın masal kahramanlarının, kendilerine biçilmiş kadere karşı gelerek gerçek yaşamın veya kendi isteklerinin peşine düşmelerine anlatıda önemli bir zaman ayrılır ve tekrarlanan sahnelerle karakterlerin yaşadığı dönüşüm süreci anlatının söyleminin inşasında temel nokta olarak karşımıza çıkar.

Filmin hikâyesi her ne kadar metinlerarası ilişkiler ile karmaşıklaşmış görünse de metin analizinin de ortaya koymuş olduğu gibi belirli bir düzen içinde ilerler. Düzenin kaynağında yola çıış, erginlenme ve dönüş eşiklerinin sorgulanmaya açık da olsa varlıklarını sürdürdükleri ve film zamanını biçimlendirdikleri görülür. Özellikle erginleme bölümü kendi içinde üç gün ve üç geceye bölünerek belirli bir zaman şeması içinde tamamlanır. Postmodern eklenti "mutlu son"a ulaşıldıktan sonra hikâyenin bitmemesi, yeniden ormana giriş ile kaosun geri dönmesi ile gerçekleşir. Böylece hikâye yeniden açılır, karakterler istem yönlerini kaybetmiş bir şekilde yeniden ormana kaçarlar ve tekrar erginleme ve dönüş aşamalarına girerler.

Karakterizasyon: Film, klasik masallardaki toplumun çizmiş olduğu cinsiyet rollerine yapısökümcü müdahalelerde bulunur. Bu müdahaleler en çok Fıııncı ve Karısının ilişkisinde karşımıza çıkar. Fırıncı; iyi, dürüst, ama bir o kadar beceriksiz ve çok da akıllı olmayan bir insandır. Karısına karşı sevgi dolu, anlayışlı ve yumuşak huyludur, ancak aynı zamanda da toplumsal cinsiyet temelli kadın-erkek rollerine sıkı sıkıya bağılır. Cadı, Fırıncının ailesini lanetlediği için çocukları olamamaktadır. Fırıncı, Karısı çocuk istediği için Cadının teklifini kabul eder ve büyü için gerekli nesneleri aramak üzere yolculuğuna başlar. Karısı ortak sorunlarının çözümü için birlikte çalışmaları gerektiğini düşünür ve ona eşlik etmek ister. Ancak Fırıncı buna şiddetle karşı çıkar. Öncelikle orman bir kadın için tehlikelidir, ayrıca onun ailesi/evi lanetlenmiştir dolayısıyla bu laneti kaldırmak da onun sorumluluğundadır. Karısı onun bu söylemine karşıık olarak "bizim evimiz" der ve yaşamlarının ortaklı̆ına dikkat çeken bir söylem üretir. Ancak Fırıncı her seferinde "benim evim" diyerek Karısı ile ortaklaşa, eşit bir birliktelik düşüncesine sahip olmadığını dile getirir. Fırıncının, Karısı ile olan konuşmalarında ataerkil söylemi sıklıkla ürettiği görülür. Hiç kuşkusuz en dikkat çekicilerinden biri lanet kalktıktan sonra bebekleri olunca; "Ben onunla büyüyünce ilgilenirim" demesi ve bebeği kucağına dahi almak istememesidir. 
Filmin genelinde Fırıncı ve Karısı arasındaki ilişki toplumsal cinsiyet rollerine dair bir eleştiri olarak okunabilir. Kadının karakter özellikleri ve eylemleri de bu eleştiriyi destekler niteliktedir. Kadın eşinden daha akıllı, mantıklı ve sorumluluk sahibi görünmektedir. Eşine karşı anlayışlı ve onun eksik yönlerini tamamlamaya çalışan bir tavra sahip olan Kadın, kocasının iktidarına karşı gelmez ancak kendi aklıyla hareket etmekten de çekinmez.

Fırıncının Karısı, Kocasının peşinden ormana girer. Amacı eşine evde unuttuğu şalını vermektir. Kadın laneti kaldıracak olan şeyleri birlikte aramayı bir kez daha teklif eder. Kocası bu fikri onaylamaz, o da diretmez ve eve doğru yola çıkar. Ancak yolda Külkedisi ile karşılaşır. Külkedisinin altın ayakkabısını görünce eve gitmez ve ayakkabıyı almanın yollarını aramaya başlar. Böylece Kadının yolculuğu da başlamış olur. Laneti kaldırmak için gerekli olan nesneleri arayan Kadın, toplumsal rollere karşı öznelleşme istemiyle hareket eden postmodern anlatı kahramanlarından biri olarak şekillenmeye başlar. Anlatı, temsil bağlamında kadın kahramanın cesaretini, aktifliğini ve zekâsını görünür kılar ve olay örgüsünde "özne" olarak yer almasını sağlar. Ancak bunun yanında Kadının ironik bir şekilde toplumsal cinsiyet rollerine uygun hareket ettiği görülür. Bu durum en çok Külkedisi ve Prens ile karşılaştı̆̆ı sahnelerde göze çarpar. Külkedisi ile ikinci karşılaşmasında ona neden prensten kaçtığını sorar. Prensten kaçması ona göre mantıksızdır; "Eğer bir prens beni arasaydı kesinlikle saklanmazdım." diyerek bir kadının en büyük hayaline sahip olan Külkedisinin davranışını yargılar. Külkedisi neden kaçtığını ona açıklamaya çalıştığında ise söylediklerini dinlemez. Prens hakkında ve balo hakkında sorular sormaya devam eder. Bu sahneler filmin başından itibaren bağımsız, akıllı bir Kadın olarak sunulan Fırıncının Karısını klasik masal anlatılarında bir prensin kendisini kurtarmasını, sevmesini isteyen kadınlardan birine dönüştürür. Film tam da bu noktada eleştiri getirdiği toplumsal cinsiyet rollerini ve ataerkil söylemi yeniden üretir.

Prens ile her karşılaştığında heyecanlanan ve ona hayranlıkla bakan Kadın, filmin sonunda Prens ile öpüşür ve hemen ardından da uçurumdan aşağı düşerek ölür. Prense karşı zaafı onu sadakatsiz bir eşe dönüştürürken, masalın sonunda mutlu bir sona erişme hakkının da elinden alınması anlatı içinde meşrulaştıılır. Filmde Külkedisinin hikâyesinde de benzer bir yapının kurulması dikkat çekicidir.

Külkedisi üç gece üst üste Prensten kaçar. Kaçmasının altında yatan neden, gerçekten kendi isteğinin ne olduğundan emin olamamasıdır. Prens ve kendisinin ne istediği hakkında düşünen 
Külkedisinin sözleri oldukça dikkat çekicidir: "Onun istediğinin ben olmadığımı biliyorken, o benim kim olduğumu öğrenirse? Ya da ben nasıl bir prens hayal ediyorum? Ama sonra ne istediğini anlayana kadar kim olduğunu nasıl bilirsin? Ki ben bilmiyorum. Öyleyse neyi seçersin her şeyin ters gittiği gözden uzak güvende kendin olmayı mı yoksa her şeyin harika olduğu ama asla ait olmayacağını bildiğin yeri mi?" Tüm bu sorgulamaların ve bu soruların ardından kararı Prensin vermesi için ayakkabısını merdivene bırakması, Fırıncının Karısının hikâyesindeki ironinin yeniden belirmesine neden olur. Film boyunca kaderini kendi çizmek istiyormuş gibi görünen Külkedisi, aniden kararsız ve düşünmekten bile üşenen bir kadına dönüşerek erkek kahramanın yol göstericiliğine ihtiyaç duyan bir karaktere dönüşür. Prensin onu bulmasının ardından, Prensle evlenerek Külkedisi masalının klasik sonuna erişir.

Külkedisi masalının sonu olan düğün tüm kahramanların hikâyesinin de mutlu sona erdiği anı gösterir: Fırıncı ve Karısı bebeklerine kavuşmuştur, Jack ve annesi artık zengindir, Cadı genç ve güzeldir, Rapunzel ve Prens birliktedir. Ancak filmin kahramanlarının yolculuğunun sona erdiğini düşündüren bu sahne de yapısöküme uğrar ve fasulye sırığından dünyaya inen Dev Kadının yarattığı kaos ile tüm dengeler altüst olur. Kahramanlar yeniden ormana dönerler, daha doğrusu ormana kaçarlar. Belirsizliklerle dolu olan orman bu sefer sığındıkları ve saklandıkları bir mekâna dönüşür. Ancak orman değişmiştir, anlatıcı kahramanların içinde bulunduğu durumu şöyle aktarır: "Ancak ormandan geçerken hiçbir yerde tanıdık yollar yoktu. Hayatlarıysa beklenmedik bir hal almak üzereydi."

Ormana girişleri ile birlikte tüm kahramanlar yeni bir maceraya atılmış olur. Filmin anlatısı bu noktadan sonra tüm masalların sonuna bir alternatif son oluşturacak şekilde kurulur. Fırıncı ve Karısı evlerinin yolunu bulmaya çalışırken Kırmızı Başlıklı Kız ile karşılaşırlar. Önce annesini, ardından da ormanda Büyükannesinin evine giden yolu bulamayan Kırmızı Başlıklı Kız kaybolmuştur ve korkmaktadır. Fırıncının Karısı, Kırmızı Başlıkı Kızı teselli eder ve onu yanlarına alarak yollarına devam ederler. Bir süre yürüdükten sonra Prensin kahyası, Külkedisinin üvey annesi ve kız kardeşleri ile karşılaşırlar. Krallığa saldıran düşman -Dev Kadın-ağaçların arasından belirir ve Kocasını öldüren Jack'i kendisine vermelerini ister. Herkes korksa da çocuğu korumak için yalan söyler. Ancak bir anda ortaya çıkan Cadı, Dev Kadından kurtulmak için Jack'i bulup ona vermek ister. Bu sırada Jack'in annesi de tartışmaya dahil olur. Dev Kadını söylediği sözlerle kızdırdığı için kâhya Anneyi iterek yere düşürür, Deve Jack'in kulede saklandığı yalanını söyler. Dev uzaklaşırken Fırıncı, bu sorundan kurtulmak istiyorlarsa birlikte hareket etmeleri gerektiğini belirtir ve kadın kahramanlara rehberlik edecek olan "erkek kahraman" rolünü üstlenir. 
Kâhya ve Külkedisinin Annesi ile kız kardeşleri kaçarlar. Yerde baygın halde yatan Anne kendine gelir ve Jack'i Fırıncıya emanet ettikten sonra ölür. Fırıncı, Anneye verdiği sözü tutmak için Jack'i aramaya karar verir. Karısı ile Jack'i aramak ister ancak bu sefer de Kadın birlikte değil, ayrı ayrı aramaları gerektiğini düşünür. Bebeği Kırmızı Başlıklı Kızın kucağına veren Kadın ile Fırıncı farklı yönlere doğru yürüyerek birbirlerinden uzaklaşır. Bu ayrılık ana kahramanların hikâyesinin de birbirinden ayrılması anlamına gelir. Kadın, Prens ile karşılaşır. Bu karşılaşma daha önce bahsedildiği üzere Kadının eşine olan sadakatsizliğinin sonucu olarak ölmesiyle sonuçlanır. Filmin ana kadın kahramanının ölümü klasik masal anlatılarının sonuna dair yapısökümü olarak okunsa da aslında erkek egemen söylemin filmin geneline nasıl hâkim olduğunu daha da aleni hale getirir. Kadını tatı sözlerle baştan çıkaran ve ardından onu öpen Prens eşine (Külkedisi) olan sadakatsizliği için cezalandırılmaz; filmde sıklıkla dile getirildiği gibi o bir Prenstir, çapkın olmak ve kadınlara karşı flörtöz davranmak ona özgü özelliklerdir ve bir nevi onun hakkıdır. Dolayısıyla filmin anlatısı içinde Kadın zafiyet gösteren taraf, hatalı olan kişi olarak konumlandırılır ve cezalandırılması bu yolla gerekçelendirilir.

Bu noktada filmdeki kadın kahraman temsilerine dair bir parantez açmak gerekir: Cadı, Fırıncının Karısı, Külkedisi, Kırmızı Başıklı Kız. Filmin başlangıcında tüm kadın kahramanlar ne istediğini bilen ve kaderin onlara verdiğine razı olmak istemeyen, yani öznelleşmeye çalışan ve kalıpları yıkarak kendi akılları ile hareket eden karakterler olarak gösterilir. Bu güçlü kadın kahramanların istekleri, hedefleri ve arzuları olayların ilerleyişini/gelişimini sağlayan ana etkendir. Dolayısıyla aslında filmin ana kahramanlarının kadınlar olduğu söylenebilir. Ancak filmin sonuna doğru ilerlenirken tüm bu güçlü kadın kahraman temsilleri istenç sahibi olmaları nedeniyle kaos ortamının ve düzenin bozulmasının sorumlusu olarak suçlanırlar: Cadı genç ve güzel olmak istemese, Fırıncının Karısı çocuk istemese, Külkedisi Prensten kaçmasa... Sonunda tüm bu isteklerin yarattığı kaos ortamını sonlandırmak yani "kadın"ın sebebiyet verdiği sorunları çözümlemek erkeğe düşer. Fırıncı Jack, Kırmızı Başııkı Kız ve Külkedisi ile hareket ederek Dev Kadını öldürür. Sihirli ormana yeniden huzur hâkim olurken, ne yapacağını, nereye gideceğini bilmeyen bu üç kişiye evini açarak onlara birer amaç veren kahraman da Fırıncı olacaktır. Filmin sonunda isteklerinin peşinden kararılıkla giden tüm kadın kahramanlar ölürken (Cadı, Fırıncının Karısı), Külkedisi ve Kırmızı Başlıklı Kız bağımsız karakterler olmak yerine erkek egemen düzenin gereklerine uyum göstermenin bir göstergesi olarak Fırıncı ile birlikte yaşamayı tercih ederler. 
İki güçlü kadın kahramanın ölümü ilişkili oldukları karakterlerin erginlenmesinin tamamlanmasını da sembolize eder: Bebeği kucağında bile tutamayan Fırıncı, bebeğinin hem annesi hem de babası olacağını söyler, ayrıca Jack ve Kırmızı Başıııı Kızın sorumluluklarını da üstlenir; Jack ve Kırmızı Başlıklı Kız çocukluktan çıkarak kendi kararlarını verebilecek olgunluğa erişir; Rapunzel annesinin (Cadı) anlattı̆̆ı o ürkütücü dünyayı dolaşmak için Prensle yola çıkar, Külkedisi nerede ve kiminle yaşayacağına karar verir (annesini simgeleyen ağaç da ölmüştür). Kısacası filmde tüm anne figürlerinin ölümü çocukların özgürleşmesinin, erginlenmelerinin tamamlanmasının bir gereği olarak sunulur.

Ses ve Odaklanma: Son olarak, anlatının söyleminin değerlendirilmesinde anlatım ve odaklanmanın (olayları kim görüyor/algılıyor/yargılıyor) filmde nasıl karşımıza çıktığına değinmek yerinde olacaktır. Filmde dışöyküsel bir anlatııı vardır. Filmin başlangııında dış ses kahramanları tanıtır ve film boyunca kritik anlarda anlatıcı olarak hikâyeye dâhil olur. Olayları dışarıdan biri gibi anlatır ve kahramanların kişilikleri, yaptıkları eylemler ya da içinde bulundukları duruma dair yorumda bulunmaz. Filmin sonunda, nesnel bir tavırla filme dâhil olduğu düşünülen dış sesin Fırıncı olduğu anlaşııır. Fırıncı, filmin son sahnesinde Külkedisi, Kırmızı Başlıklı Kız ve Jack'e bir masal anlatmaya başlar ve anlattığı masal aslında kendi hikâyeleridir. Filmin metninde yapılan bu tercih ile aktarılan/anlatılan tüm hikâyenin aslında ana erkek kahramanın gördüğü/algıladığı/yargıladığı şekliyle izleyiciye sunulduğu anlaşılır. Bu durumda Sihirli Orman filminde kadın kahramanın erkek egemen bakış açısıyla inşa edildiği ve sunulduğu bir söyleme sahip olduğunun bir diğer göstergesidir.

Film şu sözlerle son bulur: “Dikkat et dilediğin şeylere, dilekler bizim çocuklarımızdır. Aldıkları yola dikkat et, gerçekleşen dilekler bedelsiz değildir." Dileklerin sahibi olan tüm kadın kahramanların ölümünü bir kez daha meşrulaştırarak sonlanan film, yapısökümcü müdahalelerle klasik masal anlatılarındaki ataerkil söylem ve ideolojiyi yok etmeye/eleştirmeye çalışıyor gibi görünse de aslında bu söylemi yeniden üretmekten öteye gidemez.

Sihirli Orman örneğinin sesle ilgili olarak bir niteliği de müzikal sahneler bakımından yoğun bir anlatıma sahip olmasıdır. Müzikal ifade ile karakterler ne hissettiklerini müzik, söz ve performans aracılı̆̆ı ile aktararak, kendi iç dünyalarının anlatııısı konuma gelirler. 


\section{SONUÇ}

Bu çalışmada Sihirli Orman (2014) filmi postmodern bir masal uyarlaması olarak ele alınmış ve filmin anlatı yapısı ile merkezi karakterleri temel alınarak anlatının söylem analizi yapılmıştır.

Sihirli Orman, farklı masal içerik ve kahramanlarının bir araya getirilmesi ile metinlerarası bir anlatı örüntüsü inşa eder. Geçmiş zaman hikâyelerini yeniden gündeme taşıması ve onları yapısöküme uğratması ile postmodern metin nitelikleri taşır. Özellikle kadın masal kahramanlarının öznelleşme süreçlerini gündeme taşıması ve toplumsal cinsiyet rollerini sorgulamaya açması ile anti-masal olarak da okunmaya açık bir metin olsa da, anlatının söylem analizi ile yüzeydeki bu eleştirel bakış açısının, yerini var olan toplumsal iktidar ilişkileri ile ataerkil toplumsal cinsiyet rollerinin yeniden üretildiği katmanlara bıraktığı görülmüştür.

Çalışmada Campbell'ın Kahramanın yolculuğu modelinden yola çıkılarak dört farklı masalın birbiri içine girdiği örüntü analiz edilmiş ve klasik dramatik anlatı yapısına postmodern müdahalelerde bulunulduğu tespit edilmiştir. Ardından Genette'in anlatısal metinlere yönelik önerdiği anlatının söylem analiz metodu özellikle karakter gelişimleri ve olay arketipleri arasındaki nedensellik ilişkisine odaklanarak hikâye (içerik), anlatım (söyleme) ve metin (sunum) düzeylerinde incelenmiştir.

Son olarak Sihirli Orman filminin, postmodern bir masal uyarlaması olarak kabul edilse de, klasik arketipleri dönüştüren bir anti-masal olmaktan uzak, var olan toplumsal iktidar ilişkilerini sürdüren bir söyleme sahip olduğu tespit edilmiştir. Lyotard'ın (1997) postmodern fabl kavramsallaştırmasında gündeme getirdiği şekliyle metnin iyi ve kötü karakterler, mutlu son veya belirli bir mesaj içermemesi ile ilgili önermelerini taşımasına karşın Sihirli Orman filmi örneğinde metinlerarasılığın getirdiği sınırlardaki soruşturma biçimlerinin ataerkil söylemi sürdürdüğü ve yeniden ürettiği görülmüştür.

\section{EXTENDED ABSTRACT}

The $20^{\text {th }}$ century witnessed the rise of postmodernity and the rejection of a whole traditional storytelling strategies based on causation and the progressive archetypal construction of the narrative. Basic gender roles, usual plots, known lessons to be learned and archetypes became the subjects to be deconstructed. The methods such as intertextuality, pastiche and parody, deconstruction, decentralization evoked the emergence of anti-fairytale as a new aspect of postmodern narrative. The deconstructive intervention has mostly made apparent the representation of women characters and the 
archetypes they have occupied. The critical and feminist perspective focused primarily the transformation, or the purge of the gender roles assigned to heroines or women characters from villains to secondary / supporting characters such as mothers, servants or mentors. But these critical texts reproduce the existing social power relations, the ideology of chosen one myth despite the postmodern deconstructive intervention.

In the scope of this research, the film Into the Woods is analyzed from a critical perspective, as a postmodern narrative and an anti-fairytale model including various classical fairytales (Little Red Riding Hood, Cinderella, Rapunzel, Jack and the Beanstalk). The narrative structure of this film expands the postmodern deconstruction from the level of the transformation of characters to the intertextual development of story. Into the Woods, keeps the disruption of gender roles but also deals with the storylines of the classical texts. While interrogating the journey of a female character, the film breaks the flow of the stories and reproduces a mix of tales intersected into the wood.

Data collected by the analysis and categorization of the film's narrative structure in the context of Campbell's model for Hero's journey is analyzed by Genette's critical discourse analysis methodology for the narrative texts including levels such as story (content), expression and text (presentation) (Hunt, Marland et al., 2015: 54). Critical discourse analysis has been used to decode the reproduction of power relations in the text of the film Into the Woods.

The discourse of intertextually developed story (content), expression and the presentation interrogating the traditional and classical dramatic flow, constructs the archetypal heroes and heroines as subjects struggling against their destiny. Like many postmodern fairytale adaptation, the expression highlights the gender roles from a feminist perspective through the actions / interactions they have taken. But, the story (content) reproduces the dominant existing power relations and patriarchal ideology. Consequently, Into the Woods as a postmodern fairytale adaptation can not maintain the critical perspective in discourse and in spite of postmodern interventions which breaks the traditional archetypal journey model, reproduces dominant and existing social power relations, especially the patriarchal perspective on lonely, powerful woman characters. 


\section{KAYNAKÇA}

Agvan, Ö. \& Asutay, H. (2018). Bir Anti-Masal Örneği Olarak Cam Ayakkabıları Reddeden vejetaryen Külkedisi. Humanitas Uluslararası Sosyal Bilimler Dergisi, 6(11), s. 225-238.

Bacchilega, C. (1997). Postmodern Fairy Tales: Gender and narrative Strategies. Philadelphia: University of Pennsylvania Press.

Benjamin, W. (1995). Son Bakışta Aşk. İstanbul: Metis Yayınları.

Bostan, A. \& Kırel, S. (2018). Postmodern Dönem Disney Prenses Anlatılarında İnşa Edilen Kadın Temsilinin Moana Örneği Üzerinden İncelenmesi. TRT Akademi, 3(5), s. 1-27.

Campbell, J. (2010). Kahramanın Sonsuz Yolculuğu. İstanbul: Kabalcı Yayınevi.

Dervişcemaloğlu, B. (2007, 03 19). Gérard Genette'e göre Anlatı Söylemi. www.ege-edebiyat.org: http://www.ege-edebiyat.org/modules.php?name=News\&file=article\&sid=263 adresinden alındı

Eliade, M. (2016). Mitlerin Özellikleri. (Ç. S. Rifat, Dü.) İstanbul: Alfa Yayıncılık.

Evecen, G., \& Can, A. (2017). Belgesel filmde anlatı-anlatıcı ilişsisi: "Grizzly Man". Selçuk Iletişim(10), 283-294.

Hunt, R. E., Marland, J., \& Rawle, S. (2015). Film Dili. i̇stanbul: Literatür Yayıncılık.

Lyotard, J. F. (1997). A Postmodern Fable. USA: University of Minesota Press.

Propp, V. (2008). Masalın Biçimbilimi. İstanbul: Türkiye İş Bankası Kültür Yayınları.

Sayılgan, Ö. (2014). Etkileşimli Drama Olarak Dijital Oyunlar 'Etkileşimliliğin İdeolojisi' Bağlamında Oyuncu Alımlama Partikleri. İstanbul: İstanbul Üniversitesi Radyo TV ve Sinema Anabilim Dalı. Yayınlanmamış Doktora Tezi.

Sezer, M. Ö. (2018). Masallar ve Toplumsal Cinsiyet. İstanbul: Kor Kitap.

Sözen, M. (2008). Anlatıcı kavramı, sinematografide anlatıı tipolojisi . Selçuk Illetişim, 167-182.

TDK (2020) https://sozluk.gov.tr/

Tecimer, Ö. (2006). Sinema: Modern Mitoloji. İstabul: Plan B Yayınları.

Tunalı, D. (2017). Popüler Masallardan Sinemaya Yapılan Uyarlamalrda Kültürel Antropolojik Süreklilik ve Dönüşüm. Uluslararası Sosyal Araştırmalar Dergisi, 10(49), 362-372.

Ulu Aslan, E. (2018). Feminist Yazının Postmodern Ifadesi: Masal Parodileri. Uluslararası Sosyal Araştırmalar Dergisi, 11(60), s. 209-219.

Warner, M. (2015). Bir Zamanlar Bir Ülkede... Masalların Kısa Tarihi. İstanbul: Yapı Kredi Yayınları.

Wendranirsa, T. S. (2014). Magic as a Forma of oppression Towards Women: Gender Ideology in Maleficient. Paradigma Jurnal Kaijan Budaya, 5(1), 68-78.

Young, J. (2005). Joseph Cambell. Dictionary of Modern American Philosophy. 022019 tarihinde http://www.folkstory.com/campbell/scholars_lif (Godvin-Jones, 2014)e.html, adresinden alındı

Zipes, J. (2018). Peri Masalları ve Yıkma Sanatı. (Z. Ç. Çev. Kanburoğlu, Dü.) İstanbul: Alfa Yayın. 